УДК 658:640.4(045)

\title{
МЕТОДИЧНІ ПІДХОДИ ДО ОЦІНЮВАННЯ ЕКОНОМІЧНОГО ПОТЕНЦІАЛУ ПІДПРИЕМСТВА ГОТЕЛЬНОГО ГОСПОДАРСТВА
}

\section{METHODICAL APPROACHES TO THE ASSESSMENT OF THE ECONOMIC POTENTIAL OF THE HOTEL ESTABLISHMENT ENTERPRISE}

\author{
Роскладка Наталія Олександрівна \\ доктор економічних наук, профресор, \\ Київський національний торговельно-економічний університет \\ ORCID: https://orcid.org/0000-0001-7333-4050 \\ Вівсюк Ірина Олександрівна \\ аспірант, \\ Київський національний торговельно-економічний університет \\ ORCID: https://orcid.org/0000-0001-9170-0886 \\ Roskladka Nataliia, Vivsiuk Iryna \\ Kyiv National University of Trade and Economics
}

\begin{abstract}
У статті досліджено та проаналізовано трактування поняття «оцінка економічного потенціалу» різними вченими. На основі проведеного дослідження удосконалено сутність поняття «оцінка економічного потенціалу підприємства готельного господарства». Вивчено, охарактеризовано та узагальнено методичні підходи до оцінювання економічного потенціалу та визначено перелік методів, за допомогою яких можна досягти поставленої мети: визначення рівня ефективної діяльності, конкурентоздатності та позиції на ринку, фрінансової стійкості тощо. Запропоновано вдосконалений методичний підхід до оцінювання економічного потенціалу, зокрема, для підприємств готельного господарства, що дасть можливість проаналізувати ефективність діяльності закладу та визначити стан економічного потенціалу через економічну стресостійкість.
\end{abstract}

Ключові слова: готельне господарство, економічний потенціал, оцінка економічного потенціалу, конкурентоспроможність, економічна стресостійкість.

В статье исследована и проанализирована трактовка понятия «оценка экономического потенциала» разными учеными. На основе проведенного исследования усовершенствовано сущность понятия «оценка экономического потенциала предприятия гостиничного хозяйства». Изучены, охарактеризованы и обобщены методические подходы к оценке экономического потенциала и определен перечень методов, с помощью которых можно достичь поставленных целей: определение уровня эфрфективной деятельности, конкурентоспособности и позиции на рынке, финансовой устойчивости и т.д. Предложен усовершенствованный методический подход к оценке экономического потенциала, в частности, для предприятий гостиничного хозяйства, что позволит проанализировать эфффективность деятельности заведения и определить состояние экономического потенциала через экономическую стрессоустойчивость.

Ключевые слова: гостиничное хозяйство, экономический потенциал, оценка экономического потенциала, конкурентоспособность, экономическая стрессоустойчивость.

The success of the hotel business in the hotel services market is the result of sound management decisions based on assessing the economic potential of the company. Internal factors influencing the enterprise. The instability of the external environment encourages the assessment of the economic potential of the hotel industry. The article investigates and analyzes the interpretation of the concept of "assessment of the economic potential of the enterprise" by different scientists. Based on the study, the concept of "assessment of the economic potential of the hotel industry" is proposed. Many scientists have studied the issue of "assessment of the economic potential of the enterprise", but the methodological approach to assessing the economic potential of the hotel industry is not defined and needs further research and improvement in accordance with modern economic phenomena. The purpose of writing this article is to improve the methodological approach to assessing the economic potential of the hotel industry to 
understand: competitive positions in the market, financial stability, economic stress, efficiency of the hotel and more. Methodical approaches to assessing the economic potential of different authors have been studied, characterized and generalized. The existing evaluation methods are given and the list of methods by which the set goal can be achieved is determined: determination of the level of effective activity, competitiveness and market position, financial stability, etc. Effective and successful operation of hotel enterprises depends on the right management decisions based on the results obtained in assessing the economic potential. The proposed improved method of assessing economic potential is aimed at determining an integrated indicator of economic stress, which will include characteristics of financial, marketing, labor and commercial components. An improved methodological approach to assessing the economic potential, in particular, for the hotel industry, which will analyze the effectiveness of the institution and determine the state of economic potential and the level of economic stress.

Keywords: hotel industry, economic potential, assessment of economic potential, competitiveness, economic stress resistance.

Постановка проблеми. Останнім часом все більше приділяється уваги до моніторингу стану підприємства готельного господарства на ринку, до визначення конкурентних переваг закладу та недоліків, до впливу зовнішніх та внутрішніх чинників впливу на діяльність підприємства. Нестабільність зовнішнього середовища спонукає до оцінки економічного потенціалу підприємств готельного господарства.

Аналіз останніх досліджень і публікацій. Дослідженням питання «оцінки економічного потенціалу підприємства» у своїх працях займалися такі вчені: Бачевський Б.Є., Блацький О.Ф., Блонська В.І., Божко Е.А., Гавва В.Н., Кобєлєв В.М., Краснокутська Н.С., Лапіна Є.В., Матковський Р.Б., Олексюк О.І., Рєпіна І.М., Федонін О.С. та ін. Методичні підходи до оцінки економічного потенціалу розглянуто в працях таких вчених: Ажаман I.A., Жидков О.І., Сабадирьова А.Л., Бабій О.М., Куклінова Т.В., Салавеліс Д.Є., Рзаєва Т.Г., Маслак О.І., Безручко О.О., Кобець С.П., Ващенко О.М. Однак методичного підходу до оцінювання економічного потенціалу підприємства готельного господарства 3 урахуванням галузевих особливостей не визначено, тому це питання потребує подальшого дослідження та вдосконалення відповідно до сучасних економічних умов.

Формування цілей статті. Метою написання статті $€$ вдосконалення методичного підходу до оцінювання економічного потенціалу підприємства готельного господарства задля розуміння його конкурентних позицій на ринку, фрінансової стійкості, економічної стресостійкості, ефективності діяльності закладу готельного господарства тощо.

Виклад основного матеріалу Успішність підприємства готельного господарства на ринку готельних послуг є наслідком прийняття обґрунтованих управлінських рішень, основою яких $€$ оцінювання економічного потенціалу підприємства.
Вчений Блацький О.Ф. трактує «оцінку економічного потенціалу» як процес визначення його величини в натуральному, вартісному або будь-якому іншому вираженні [8]. Лапін $€$.В. тлумачить, як визначення величини економічного потенціалу тільки у вартісному вираженні в розрізі складових елементів [9].

У своїх наукових працях Кобєлєв В.М. зазначає, що «оцінка економічного потенціалу ґрунтується на визначенні потенційної доданої вартості продукції. При оцінці економічного потенціалу підприємства враховується загальна величина економічних ресурсів, якими володіє і розпоряджається підприємство, та економічні результати від їх раціонального використання» [10].

Учений Бачевський Б.Є. зауважує, що «оцінка потенціалу підприємства відображує переважно вартісну сторону процесу, вимірюється у відповідних одиницях, $€$ заключним етапом процесу діагностики та оцінювання і базується на результатах діагностиці. Кінцевий результат аналізу та оцінки відображується інтегральним узагальнюючим показником» [6].

У спільній праці Гавва В.Н., Божко Е.А. надають таке визначення: «оцінка потенціалу підприємства - це пошук сукупності характеристик, показників і властивостей, що дозволяють у достатній мірі описати підприємство та оцінити його можливості щодо забезпечення відповідної суспільної потреби в товарах (послугах) на перспективу й можливості досягнення поставлених цілей. Істотно впливає на оцінку стан зовнішнього середовища та конкуренція в галузі» [7].

Жилінська Л.О. розкриває сутність «оцінки економічного потенціалу підприємства» як визначення величини економічних ресурсів, якими володіє і розпоряджається підприємство, та економічного результату їх ефрективного використання. Оцінка економічного потенціалу підприємства може проводитися в натуральному і вартісному вимірі [11]. 
Таким чином, на основі вищенаведених думок вчених, можемо згенерувати власне розуміння щодо процесу оцінювання економічного потенціалу підприємства готельного господарства. На наш погляд, це визначення сукупних величин наявних та можливих ресурсів підприємства готельного господарства, результатів їх використання, що зводиться до розрахунку єдиного інтегрального показника для можливості визначення економічного та конкурентного стану підприємства.

Проведення оцінювання економічного потенціалу для підприємства готельного господарства ґрунтується на виборі підходу, методів, за якими відбуватиметься оцінка, ранжування показників, які максимально відображатимуть: ресурсну забезпеченість підприємства, його конкурентоспроможність, фрінансові стійкість, фрінансову стабільність, а також ефективність господарської діяльності в цілому.

Доцільним $€$ розглянути питання існуючих методичних підходів оцінки економічного потенціалу підприємства (табл. 1), провести їх аналіз та запропонувати структурований методичний підхід для підприємства готельного господарства.

На основі узагальнення існуючих підходів стає очевидним, синергетичний методологічний підхід. Відповідно до інформації, наведеної у таблиці 1 розуміємо, що синергетичний методичний підхід, що запропонував Маслак O.І., $є$ найбільш влучним для оцінювання економічного потенціалу підприємства готельного господарства, оскільки за умов адаптованого та вдосконаленого застосування цього

Методичні підходи до оцінювання економічного потенціалу підприємства

\begin{tabular}{|c|c|c|}
\hline Автори & Назва підходу & Характеристика підходу \\
\hline 1 & 2 & 3 \\
\hline \multirow{4}{*}{$\begin{array}{l}\text { Ажаман І.А., } \\
\text { Жидков O.I. } \\
\text { [1] }\end{array}$} & Результативний & $\begin{array}{l}\text { Оцінка сервісного підприємства за ефективністю } \\
\text { його діяльності, ступенем досягнення цілей, рівнем } \\
\text { задоволення потреб споживачів, частотою повторного } \\
\text { надання послуг (питома вага постійних клієнтів). }\end{array}$ \\
\hline & $\begin{array}{l}\text { Факторний } \\
\text { (кореляційно- } \\
\text { регресивний) }\end{array}$ & $\begin{array}{l}\text { Оцінюється вплив окремих фракторів та виявляються } \\
\text { ті, що в найбільшій мірі впливають на спроможність } \\
\text { досягнення цілей сервісного підприємства. }\end{array}$ \\
\hline & $\begin{array}{l}\text { Експертно- } \\
\text { рейтинговий }\end{array}$ & $\begin{array}{l}\text { Формування рейтингу підприємства на основі } \\
\text { комплексної оцінки експерта, яка враховує вагу кожного } \\
\text { показника для оцінки сукупного економічного потенціалу. }\end{array}$ \\
\hline & Аналоговий & $\begin{array}{l}\text { Оцінка економічного потенціалу в порівнянні } \\
\text { з основними конкурентами. }\end{array}$ \\
\hline \multirow{3}{*}{$\begin{array}{l}\text { Сабадирьова А.Л., } \\
\text { Бабій О.М., } \\
\text { Куклінова Т.В., } \\
\text { Салавеліс Д.Є. } \\
\text { [2] }\end{array}$} & Витратний & $\begin{array}{l}\text { Поєднує методи, що визначають вартість об'єкту оцінки } \\
\text { на основі витрат на його створення і використання. }\end{array}$ \\
\hline & $\begin{array}{c}\text { Порівняльний } \\
\text { (ринковий) }\end{array}$ & $\begin{array}{l}\text { Дає можливість визначити вартість об'єкту оцінки на } \\
\text { базі співставлення з об'єктами існуючих ринкових угод. }\end{array}$ \\
\hline & $\begin{array}{l}\text { Результативний } \\
\text { (дохідний) }\end{array}$ & $\begin{array}{l}\text { Оцінює вартість об'єкту оцінки на основі чистого доходу } \\
\text { та результатів від його використання. }\end{array}$ \\
\hline \multirow{3}{*}{$\begin{array}{l}\text { Рзаєва Т.Г. } \\
{[3]}\end{array}$} & Ресурсний & $\begin{array}{l}\text { Дослідження економічного потенціалу за ресурсними } \\
\text { показниками забезпечення діяльності }\end{array}$ \\
\hline & Економічний & $\begin{array}{l}\text { Дослідження економічного потенціалу за показниками } \\
\text { результативності функціонування підприємства }\end{array}$ \\
\hline & Інфрормаційний & $\begin{array}{l}\text { Дослідження економічного потенціалу за показниками } \\
\text { адаптації діяльності до середовища господарювання }\end{array}$ \\
\hline $\begin{array}{l}\text { Маслак O.I., } \\
\text { Безручко О.O. } \\
{[4]}\end{array}$ & Синергетичний & $\begin{array}{l}\text { Визначення набору показників, що відображають } \\
\text { основні складові економічного потенціалу (виробничо- } \\
\text { технічна, трудова, маркетингова, фрінансова, санаційна, } \\
\text { стратегічна, організаційно-управлінська). }\end{array}$ \\
\hline $\begin{array}{l}\text { Кобець С.П., } \\
\text { Ващенко О.М. } \\
\quad[5]\end{array}$ & Комплексний & $\begin{array}{l}\text { Оцінка структурних складових економічного потенціалу } \\
\text { підприємства (майновий, виробничий, інвестиційний, } \\
\text { фрінансовий потенціали). Підхід базується на доступних } \\
\text { даних публічної звітності, є універсальним і дозволяє } \\
\text { отримувати кількісні оцінки. }\end{array}$ \\
\hline
\end{tabular}


підходу в досліджуваній області можна провести оцінку потенціалу задля визначення економічної стресостійкості.

На основі проведеного аналізу наукових праць багатьох вчених, зокрема Аджамана O.I. та Бачевського Б.Є., було згруповано перелік методів оцінювання економічного потенціалу підприємства, зокрема:

- за спрямованістю (методи оцінки внутрішнього середовища підприємства, методи оцінки зовнішнього середовища підприємства);

- за можливістю прогнозування (методи прямої оцінки, методи непрямої оцінки);

- за галузевими особливостями (методи оцінки підприємств сорери послуг, методи для оцінки підприємств у ссрері виробництва);

- за напрямом формування інфрормаційної бази (критеріальні, експертні);

- за способом відображення результатів (експертні, математичні, методи логічного аналізу);

- за способом виконання (індикаторні, матричні);
- за необхідністю врахування динаміки процесів (статистичні, методи стратегічного аналізу) [1; 6].

Вважаємо доцільним для визначення стану економічного потенціалу підприємства готельного господарства використовувати наступні методи: прямої оцінки, індикаторні, статистичні, експертні та математичні.

На нашу думку, основними складовими для визначення стресостійкості економічного потенціалу є: фрінансова, комерційна, трудова та маркетингова складова.

На основі виокремлених складових економічного потенціалу готельного підприємства вважаємо доцільним згенерувати порядок методичного підходу оцінювання економічного потенціалу готельного підприємства (рис. 1).

Таким чином, перший етап - визначення системи показників оцінки, що відображають стан основних складових економічного потенціалу підприємства готельного господарства.

Другим етапом оцінювання економічного потенціалу $€$ визначення системних показ-

Методика оцінювання економічного потенціалу підприємства готельного господарства

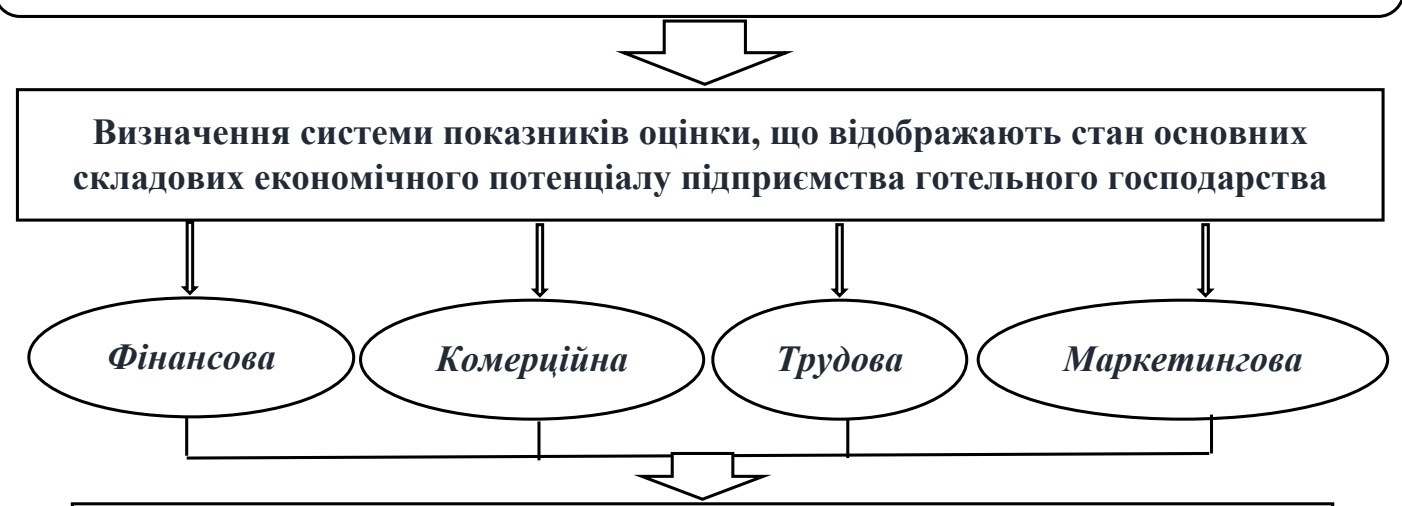

Розрахунок індексних показників для кожної складової економічного потенціалу підприсмства готельного господарства

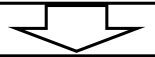

Визначення значимості (ваги) складових економічного потенціалу підприємства на основі бальних характеристик темпових змін основних показників його діяльності за допомогою методу експертних оцінок

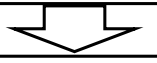

Визначення інтегрального показника економічної стресостійкості підприємства готельного господарства

Рис. 1. Методика оцінювання економічного потенціалу підприємства готельного господарства

Джерело: удосконалено автором на основі [4] 


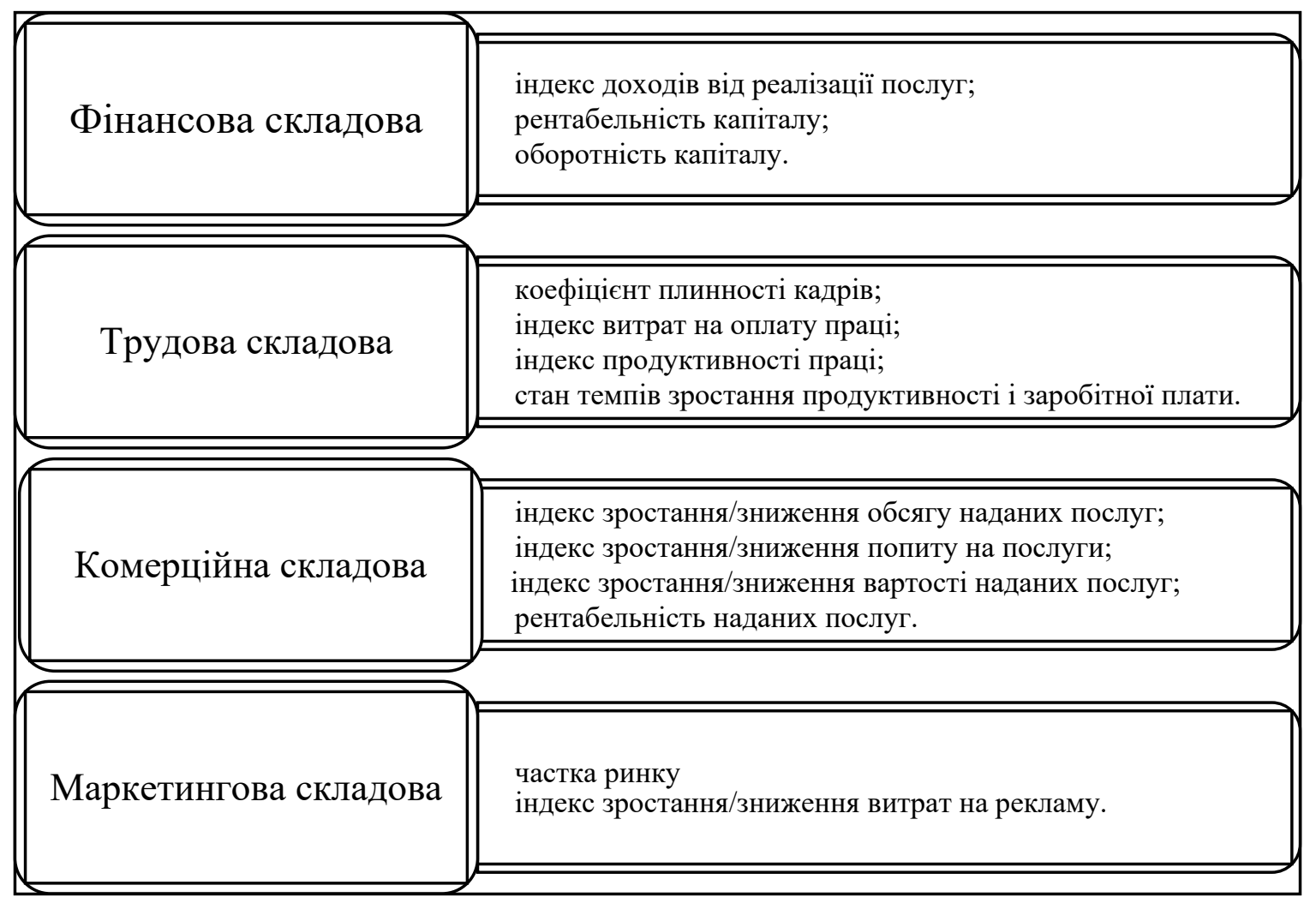

Рис. 2. Показники, що визначають складові економічного потенціалу підприємства готельного господарств

Джерело: складено автором

ників, що відображатимуть основні складові, та зведення до єдиного інтегрального показника по кожній складовій. Визначення бального рівня вагомості основних складових (як зазначалося на основі польових досліджень). Показники, за якими розраховуються складові економічного потенціалу готельного підприємства, відображені на рис. 2.

Третій етап оцінювання $€$ визначення інтегрального показника рівня економічного потенціалу підприємства на основі бальних характеристик темпових змін основних показників його діяльності за допомогою експертних оцінок.

Четвертим, завершальним, етапом методичного підходу до оцінювання $є$ визначення рівня економічної стресостійкості готельного підприємства.

Рівень економічної стресостійкості (рис. 3) можна відобразити в точці біфуркації, яка показуватиме як врівноважений стан економічного потенціалу готельного підприємства (дуже високий та високий рівень стресостійкості), так і його стан від впливу зовнішніх та внутрішніх чинників (дуже низький, низький, середній).
Висновки. Сталий моніторинг діяльності готельного підприємства допомагає спрогнозувати його розвиток під впливом нестабільних зовнішніх чинників, які безпосередньо впливають не лише на стан національної економіки, а й на фрункціонування закладів тимчасового розміщення.

Ефективна та успішна діяльність підприємств готельного господарства залежить від правильних управлінських рішень на основі отриманих результатів при оцінюванні економічного потенціалу. Запропонований удосконалений метод оцінки економічного потенціалу спрямований на визначення інтегрального показника економічної стресостійкості, який включатиме характеристику фрінансової, маркетингової, трудової та комерційної складових.

Таким чином, на основі оцінювання рівня економічної стресостійкості економічного потенціалу підприємства готельного господарства можна: визначити стан закладу, сильні та слабкі місця у діяльності готельного підприємства; спрогнозувати розвиток його діяльності; запропонувати шляхи вдосконалення. 


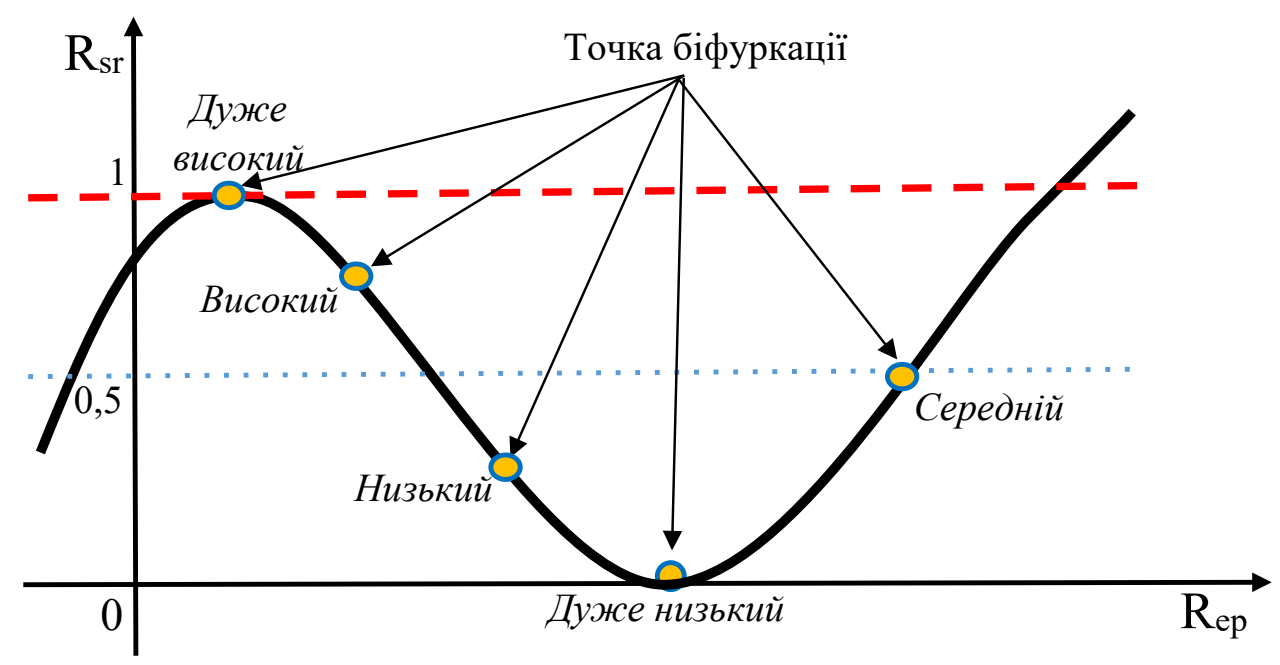

Рис. 3. Рівень економічної стресостійкості
підприємства готельного господарства

Джерело: складено автором

\section{СПИСОК ВИКОРИСТАНИХ ДЖЕРЕЛ:}

1. Ажаман І. А., Жидков О. І. Методичні підходи до оцінювання рівня розвитку економічного потенціалу сервісного підприємства. Ефрективна економіка електронний журнал. 2019. № 5. URL: http://www.economy.nayka.com.ua/?op=1\&z=7028

2. Сабадирьова А. Л., Бабій О. М., Куклінова Т. В., Салавеліс Д. Є. Потенціал і розвиток підприємства : навч. посіб. Одеса : ОНЕУ, ротапринт, 2013. 343 с.

3. Рзаєва Т. Г. Підходи до оцінки потенціалу підприємства: їх переваги та недоліки. Вісник Хмельницького національного університету. 2014. № 3. Т. 3. С. 150-155.

4. Маслак О. І., Безручко О. О. Особливості оцінювання економічного потенціалу підприємства в умовах циклічних коливань. Вісник соціально-економічних досліджень. 2013. Випуск 1. № 48. С. 121-127.

5. Кобець С. П., Ващенко О. М. Методичний підхід до оцінки економічного потенціалу підприємства. Ефрективна економіка. 2021. № 6. URL: http://www.economy.nayka.com.ua/?op=1\&z=8968

6. Бачевський Б. Є., Заблодська І. В., Решетняк О. О. Потенціал і розвиток підприємства : навч. посіб. Київ : Центр учбової літератури, 2009. 400 с.

7. Гавва В. Н., Божко Е. А. Потенціал підприємства: формування та оцінювання : навч. посіб. Київ : Центр навчальної літератури, 2004. 224 с.

8. Балацький О. Ф., Лапін Е. В., Акуленко В. Л. Економічний потенціал адміністративних та виробничих систем : монографія. Суми : Університецька книга, 2006. 972 с.

9. Лапін Е. В. Економічний потенціал підприємства : монографрія. Суми : Університецька книга, 2002. 310 с.

10. Кобєлєв В. М. Підходи до оцінки економічного потенціалу підприємства. Технічний прогрес та ефективність виробництва. 2011. № 8. С. 119-122.

11. Жилінська Л. О. Основні підходи до оцінки економічного потенціалу підприємства. Економічний часопис-XXI. 2012. № 9-10. С. 53-56.

\section{REFERENCES:}

1. Azhaman I., Zhydkov O. (2019) Metodychni pidkhody do otsiniuvannia rivnia rozvytku ekonomichnoho potentsialu servisnoho pidpryiemstva [Methodical approaches to assessing the level of development of the economic potential of the service enterprise]. Efektyvna ekonomika (electronic journal), vol. 5. Available at: http://www.economy.nayka.com.ua/?op=1\&z=7028 (accessed 22 January 2022).

2. Sabadyrova A. L., Babii O. M., Kuklinova T. V., Salavelis D. Ye. (2012) Potentsial i rozvytok pidpryiemstva [Potential and development of the enterprise]. Odesa: ONEU. (in Ukrainian)

3. Rzaieva T. H. (2014) Pidkhody do otsinky potentsialu pidpryiemstva: yikh perevahy ta nedoliky [Approaches to assessing the potential of the enterprise: their advantages and disadvantages]. Visnyk Khmelnytskoho natsionalnoho universytetu, vol. 3, no. 3, pp. 150-155. 
4. Maslak O. I., Bezruchko O. O. (2013) Osoblyvosti otsiniuvannia ekonomichnoho potentsialu pidpryiemstva $\mathrm{v}$ umovakh tsyklichnykh kolyvan [Features of estimation of economic potential of the enterprise in the conditions of cyclic fluctuations]. Visnyk sotsialno-ekonomichnykh doslidzhen, vol. 1, no. 48, pp. 121-127.

5. Kobets S. P., Vashchenko O. M. (2021) Metodychnyi pidkhid do otsinky ekonomichnoho potentsialu pidpryiemstva [Methodical approach to assessing the economic potential of the enterprise]. Efektyvna ekonomika (electronic journal), vol. 6. Available at: http://www.economy.nayka.com.ua/?op=1\&z=8968

6. Bachevskyi B. Ye., Zablodska I. V., Reshetniak O. O. (2009) Potentsial i rozvytok pidpryiemstva [Potential and development of the enterprise]. Kyiv: Tsentr uchbovoi literatury. (in Ukrainian)

7. Havva V. N., Bozhko E. A. (2004) Potentsial pidpryiemstva: formuvannia ta otsiniuvannia [Enterprise potential: formation and evaluation]. Kyiv: Tsentr navchalnoi literatury. (in Ukrainian)

8. Balatskyi O. F., Lapin E. V., Akulenko V. L. (2006) Eknomichnyi potentsial administratyvnykh ta vyrobnychykh system: monohrafiia [Economic potential of administrative and production systems: monograph]. Sumy: Universytetska knyha. (in Ukrainian)

9. Lvpin E. V. (2002) Ekonomichnyi potentsial pidpryiemstva: monohrafiia [Economic potential of the enterprise: monograph]. Sumy: Universytetska knyha. (in Ukrainian)

10. Kobieliev V. M. (2011) Pidkhody do otsinky ekonomichnoho potentsialu pidpryiemstva [Approaches to assessing the economic potential of the enterprise]. Tekhnichnyi prohres ta efektyvnist vyrobnytstva, vol. 8, pp. 119-122.

11. Zhylinska L. O. (2012) Osnovni pidkhody do otsinky ekonomichnoho potentsialu pidpryiemstva [The main approaches to assessing the economic potential of the enterprise]. Ekonomichnyi chasopys-XXI, vol. 9-10, pp. 53-56. 